\begin{tabular}{cc|c|} 
bentham open & Open Biological Sciences Journal \\
CrossMark & Content list available at: www.benthamopen.com/BIOLSCI/ \\
DOI: $10.2174 / 2352633501602010001$ & \\
\hline
\end{tabular}

\title{
The Effects of Coloured LED Light on Behaviour and Physiology in Healthy Horses
}

\author{
Joan-Bryce Burla $^{1, *}$, Iris Bachmann ${ }^{2}$, Edna Hillmann ${ }^{1}$ and Heike Schulze Westerath ${ }^{1}$ \\ ${ }^{I}$ ETH Zurich, Institute of Agricultural Sciences, Ethology and Animal Welfare Unit, Universitätstr. 2, CH-8092 Zurich, \\ Switzerland \\ ${ }^{2}$ Agroscope, Swiss National Stud Farm, Les Longs-Prés, CP 191, CH-1580 Avenches, Switzerland
}

Received: September 22, 2014

Revised: September 08, 2015

Accepted: January 20, 2016

\begin{abstract}
The use of colour light therapy to treat diseases and disorders in animals is increasingly common but only very little research has been conducted on the effects of illumination with coloured light. The present study examined to which extent coloured light causes behavioural and physiological responses in horses. Red, green, blue and yellow as well as white as a control colour were tested in 20 healthy stallions of the breed Freiberger. Coloured light was applied on five consecutive days in randomised order for 15 min each in a LED light illuminated box stall. Behaviour was observed during illumination, salivary cortisol levels were measured immediately thereafter. Elimination, activity, heart rate and temperature parameters were recorded before, during and after illumination. Results showed that "Drinking" occurred more often at yellow and body core temperature was higher at red and blue and lower at green and yellow, whereas body surface temperature was tendentially increased at all colours compared to the control white. For the majority of parameters, however, no effects were found and discovered effects often did not correspond to expectations deriving from principles of colour light therapy. A general effect of illumination, regardless of the colour, was further demonstrated for activity, heart rate and heart rate variability and absolute values of physiological and behavioural parameters indicated that the illumination with coloured light did not constitute a stressor but rather had a becalming effect on horses.
\end{abstract}

Keywords: Behaviour, body temperature, colour light, cortisol, horse, heart rate parameters.

\section{INTRODUCTION}

The use of colour light therapy in animals to treat diseases and disorders is increasingly common but only very little research has been conducted on the effects of coloured light on animals. Existing studies most often used animal models for human therapy, e.g. on wound healing [1, 2], osteoarthritis [3], motor function following embolic strokes [4], depression [5] or diabetes [6], however studies on the effectiveness of colour light therapy exist neither for horses nor other animals. Nevertheless, various forms of practical therapy applications are prevalently used in horses and other domestic animals as an alternative treatment method for disorders or diseases, e.g. dyspepsia, infections, abscesses, hematomata, arthritis, laminitis, muscle pain or nervousness [7]. After a diagnosis, the type of illumination, the choice of colour or colour combination and the duration of illumination are determined by a colour light therapist. Frequently applied types of application are selective irradiation of acupuncture points [8], partial irradiation on certain body areas [9] and total body exposure or room illumination for a holistic effect on the body. Recommendations on treatment durations vary from 10 to 20 minutes, sometimes repeated several times per day [9, 10]. Often specific therapy lamps (Bioptron $^{\circledR}$, Q.Light ${ }^{\circledR}$ ) are used, whereas the usage of LED light provides an alternative which is also utilised in human medicine $[11,12]$.

The effects of colours and coloured light on the human body have traditionally been used for centuries. The practical application of colour light therapy in horses is based on an analogy to the human field or practical experience

\footnotetext{
* Address correspondence to this authors at the ETH Zurich, Institute of Agricultural Sciences, Ethology and Animal Behaviour, Health and Welfare Unit, Universitätstr, 2, CH-8092 Zurich, Switzerland; Tel: +41 4463202 92; E-mail: jburla@usys.ethz.ch
} 
of animal colour light therapists. Red is described to be generally stimulating [7], leading to an increased heart rate, elevated blood circulation, and further to have a warming effect [9]. Blue is described to generally have a calming and relaxing effect by stimulating the parasympathetic nervous system $[7,10]$ and also to have a blood circulation reducing effect [7]. Green is described to induce general relaxation [7] which has a balancing effect on the cardiovascular system and further to have an anti-inflammatory effect [9]. Yellow is described to have a stimulating effect on nerves which can lead to increased activity or nervousness [10] and further is considered to be a "hot colour" [9]. Furthermore, coloured light is not only applied in alternative therapy but also in scientific medicine and research has been conducted on psychological and also therapeutic effects. Blue light $(420-470 \mathrm{~nm})$ for example is used for the treatment of jaundice in new-borns [13,14] and Seasonal Affective Disorder in adults [15]. Iyilikci et al. [16] showed an antidepressant effect for blue light by stimulation of the melanopsin-containing ganglion cells of the retina, which was not ascertainable with red light. Also different effects of red and blue light were found by Weinzirl et al. [17] regarding changes in blood-oxygen levels in the human brain and muscles. Trimmer et al. [18] found evidence that a treatment with near-infrared light $(810 \mathrm{~nm})$ can restore axonal transport in model human dopaminergic neuronal cells to control levels, and thus to improve neuronal functions in patients with Parkinson's disease.

The impact of light on the body occurs either visually or physically and chemically by stimulation of photoreceptors in skin cells. Visual impact is causing an irritation of the sensory cells in the eye [19]. Therefore, colour vision might be a precondition for colour light therapy. Studies on horses' colour vision and their ability to discriminate certain wavelengths from grey have concluded a dichromatic colour vision. Pick et al. [20] obtained significant results regarding the discrimination of blue $(462 \mathrm{~nm})$ and red $(700 \mathrm{~nm})$, but not green $(496 \mathrm{~nm})$. Blackmore et al. [21], in turn, demonstrated the ability to see blue $(470,474,482 \mathrm{~nm})$, yellow $(579,582,583 \mathrm{~nm})$ and green $(532,533,545 \mathrm{~nm})$ and a tendency for red $(609,611,615 \mathrm{~nm})$. However, Smith and Goldman [22] observed horses with the ability to distinguish all four colours (blue $470 \mathrm{~nm}$, red $617 \mathrm{~nm}$, green $538 \mathrm{~nm}$, yellow $581 \mathrm{~nm}$ ) successfully, but reported some individuals with partial colour blindness. More important for the application of colour light therapy is the mechanism of physical and chemical impact by stimulation of photoreceptors in skin cells which generate neuronal and neuroendocrine signals $[23,24]$. Hence, brightness and different wavelengths of light are supposed to specifically influence biochemical processes in body cells [7]. As a result, specialist literature on colour light therapy describes colour specific effects on body core temperature and heart rate in particular and on physical activity, relaxation or stress in general [7, 9, 10]. The temperature regulation centre is located in the hypothalamus and body core temperature is controlled endogenously [25]. Body surface temperature is subordinate to the regulation of body core temperature and participates additively in the production or release of heat [26]. The heart rate is related to circulation, respiration, temperature and metabolism; it is directly influenced by physical and psychological stressors [27] and a good indicator of activity-independent acute stress [28]. Furthermore, heart rate variability is an analytical measurement for fluctuations in the length of beat-to-beatintervals [29]. Changes in heart rate and heart rate variability are caused by a dynamic but non-additive interplay among the sympathetic and parasympathetic nervous system in the cardiovascular control [29, 30]. Heart rate variability has been shown to be a sensitive parameter of the time characteristic of physical or psychological stress [30]. Another parameter in valuation of stress is the steroid hormone cortisol, whose secretion into blood, and further via passive diffusion into saliva, responds quickly to stressors [31 - 33]. Since blood sampling is invasive and thus a potential stressor itself, non-invasive salivary cortisol sampling is a means to measure stress responses [31].

The aim of this study was to obtain general knowledge on the effects of coloured light on horses and to evaluate effects described in specialist literature. For this purpose, the effects on various behavioural and physiological parameters were investigated in 20 healthy stallions of the breed Freiberger during short term exposure to coloured light at red, blue, green and yellow in comparison to white light as control. In connection with described physiological responses to coloured light, behavioural reactions, which allow general conclusions about possibly induced stress or relaxation by the illumination, were further taken into consideration.

\section{ANIMALS, MATERIAL AND METHODS}

\subsection{Animals and Housing}

The study was conducted with 20 healthy stallions of the breed Freiberger at the Swiss National Stud Farm ${ }^{\mathrm{a}}$. The age of the animals ranged from 5 to 17 years (mean of 8.25 years), the coat colours matched the breed typically chestnut $(n=6)$, liver chestnut $(n=2)$, bay $(n=10)$ and dark bay $(n=2)$. Seventeen horses had winter coat, two were

\footnotetext{
${ }^{\text {a }}$ Agroscope, Swiss National Stud Farm, Avenches, Switzerland
} 
wearing rugs and therefore had shorter coat and one horse was clipped and wearing a rug; rugs were taken off $1 \mathrm{~h}$ before individual testing. All horses were handled on a daily base, they were accustomed to being ridden, driven or walked in a horse walker and having access to paddocks. The stallions were housed individually in box stalls of $3.0 \times 3.65$ m, provided with crib, drinker, salt lick and straw bedding (Fig. 1). Box stalls were built of solid wooden walls (up to a height of $1.30 \mathrm{~m}$ ) and upper grill panels with gaps between bars of $5 \mathrm{~cm}$ (up to a height of $2.70 \mathrm{~m}$ ), allowing visual and restricted physical contact. Housing was in accordance with the national animal welfare legislation [34]. Feeding with hay and concentrate occurred at 8:00 and 17:00, and concentrate was fed additionally at 12:00.

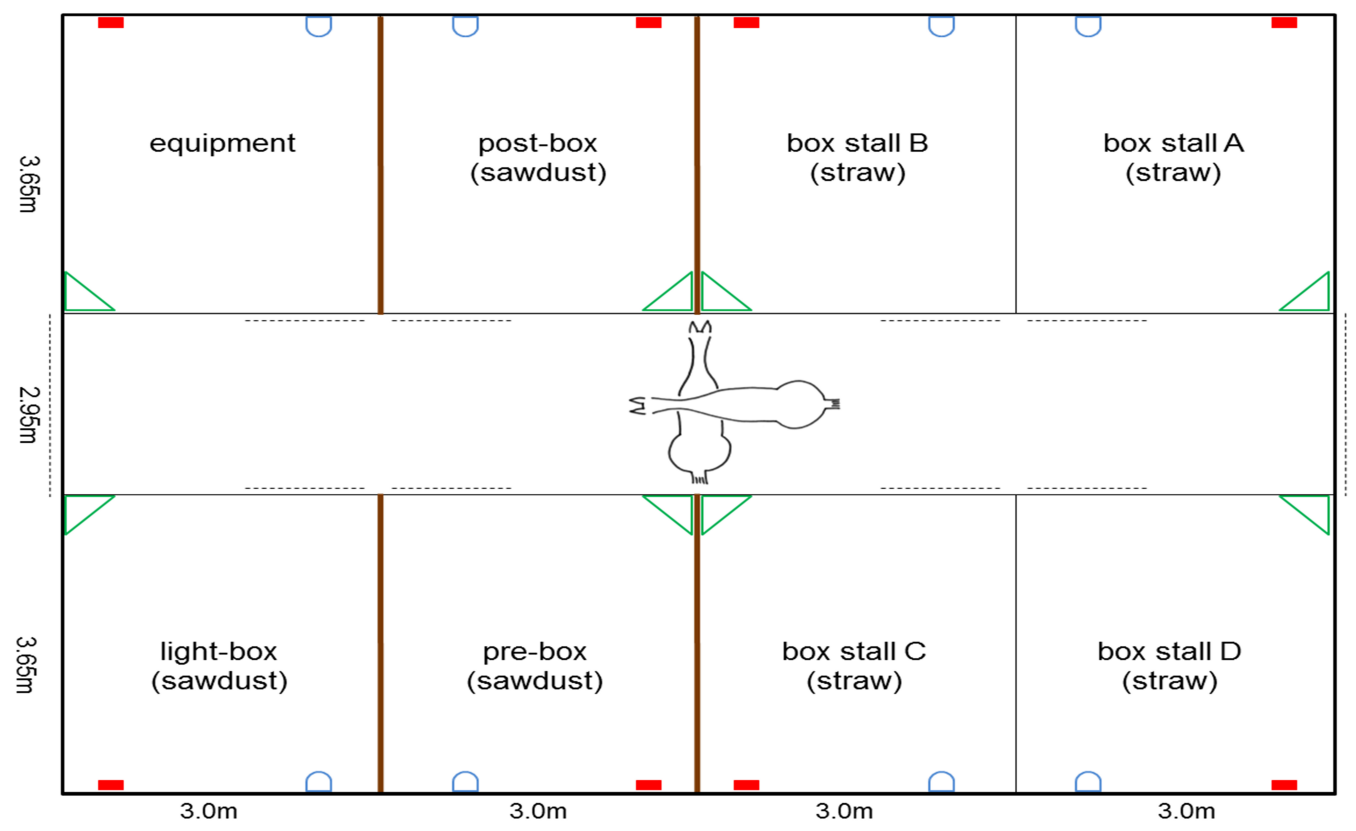

Fig. (1). Sketch of the experimental barn compartment at the Swiss National Stud Farm with four box stalls for housing of experimental animals and three experimental box stalls (pre-, light- post-box); each provided with crib, drinker and salt lick and littered with straw or sawdust.

The experiment took place in a separate barn compartment with eight box stalls, similar to all other barn compartments at the Swiss National Stud Farm (Fig. 1). The horses were brought to the experimental barn compartment one day before their first testing and stayed there for the entire test week; four box stalls were used for housing the animals, three for the experiment and one for equipment (Fig. 1). During the five experimental days, housing and feeding was performed as usual but the horses were not ridden or driven. Instead, they walked for $1 \mathrm{~h}$ in a horse walker in the morning and had $1.5 \mathrm{~h}$ individual access to a paddock $\left(150 \mathrm{~m}^{2}\right)$ every day. Except for feeding, mucking out and littering the box stalls, all handling and data recording was conducted by one person.

\subsection{Experimental Test Procedure}

The horses were tested during five weeks between November and January; in each test week four horses attended the experiment. Each horse was tested individually on five consecutive days (Monday to Friday) with the colours red, green, blue and yellow as well as white as control colour. A given animal was exposed to only one colour per day and test procedures for each horse always started at the same time of the day (9:00, 10:30, 13:00 or 14:30). Allocation of colours to the different horses and test days was randomised considering the following rules:

a. For all possible combinations of weekdays (Mon - Fri) and times of the day (9:00, 10:30, 13:00 or 14:30), every colour was realised once within the five test weeks.

b. All possible sequences of any two colours must be realised within the five test weeks and the number their occurrences was as equal as possible.

c. As many different colours as possible were tested on a given day.

The daily test procedure took about $75 \mathrm{~min}$ and was subdivided into three experimental phases (pre-, light- and postphase) of 20 min each. Between experimental phases the horse was tied in the alley for 5 min (Table 1). Pre-, light- and 
post-phase each took place in different experimental box stalls (pre-, light- and post-box) which were provided with crib, drinker and salt lick and littered with sawdust (Fig. 1). To prevent physical interactions with neighbouring horses during testing, the side walls of experimental box stalls were shut with wooden panels up to a height of $2.70 \mathrm{~m}$.

Table 1. Daily experimental test procedure for each horse with respective location (pre-, light- and post-box, alley) and recorded behavioural or physiological parameters at given phases or measurement times.

\begin{tabular}{|c|c|c|c|c|c|c|}
\hline \multirow[b]{2}{*}{ Location } & \multicolumn{2}{|c|}{ Pre-phase } & \multicolumn{2}{|c|}{ Light-phase } & \multicolumn{2}{|c|}{ Post-phase } \\
\hline & Pre-box & Tied in alley & Light-box & Tied in alley & Post-box & Tied in alley \\
\hline Time [min] & $0-20$ & $20-25$ & $25-45$ & $45-50$ & $50-70$ & $70-75$ \\
\hline Behaviour & & & $\mathrm{x}$ & & & \\
\hline Elimination & $\mathrm{x}$ & & $\mathrm{x}$ & & $\mathrm{x}$ & \\
\hline $\begin{array}{l}\text { Activity } \\
\text { (ALT-Pedometer) }\end{array}$ & $\mathrm{x}$ & & $\mathrm{x}$ & & $\mathrm{x}$ & \\
\hline $\begin{array}{l}\text { Heart beat parameters } \\
\left(\text { Polar }^{\mathbb{B}}\right)\end{array}$ & $\mathrm{x}$ & & $\mathrm{x}$ & & $\mathrm{x}$ & \\
\hline $\begin{array}{l}\text { Body core temperature } \\
\text { (Microlife Vet-Temp) }\end{array}$ & & $\mathrm{x}$ & & $\mathrm{x}$ & & $\mathrm{x}$ \\
\hline $\begin{array}{l}\text { Body surface temperature } \\
\text { (FLIR Systems) }\end{array}$ & & $\mathrm{x}$ & & $\mathrm{x}$ & & $\mathrm{x}$ \\
\hline $\begin{array}{l}\text { Salivary Cortisol } \\
\left.\text { (Salivette }^{\mathbb{B}}\right)\end{array}$ & & & & $\mathrm{x}$ & & \\
\hline
\end{tabular}

The experimental barn compartment was illuminated with ordinary fluorescent strip lights; lamps were turned on all day (7:00 - 12:00 / 13:00 - 17:00) and displayed the standard lighting in pre-, light and post-box. The exposition to the coloured light was conducted for $15 \mathrm{~min}$ after $5 \mathrm{~min}$ acclimatisation. The light-box was equipped with two high power LED lamps on the ceiling (at a height of $3.65 \mathrm{~m}$ ) to illuminate the entire rear wall and about $0.5 \mathrm{~m}$ of the floor (Fig. 2). The LED lamps ${ }^{\mathrm{b}}$ each contained 48 RGB-LEDs (16 red, 16 green, 16 blue) to generate the electromagnetic spectrum from $470-620 \mathrm{~nm}$ by additive colour mixture. To illuminate the light-box with red (625 nm), green (534 nm) and blue $(470 \mathrm{~nm})$, the corresponding LEDs were used with their maximum output (100\%). Yellow (571 nm) was mixed with red (output $41.2 \%$ ) and green (output 58.8\%), whereas white was mixed with red (output 29.4\%), green (output 35.3\%) and blue (output $35.3 \%$ ). The wavelengths of test colours were consistent with horses' ability of colour vision. For all colours, the intensity of illumination was controlled to about 240 lux. To focus the illumination on the rear wall, the side walls were painted in black and the rear wall was coated with reflecting white dispersion paint.

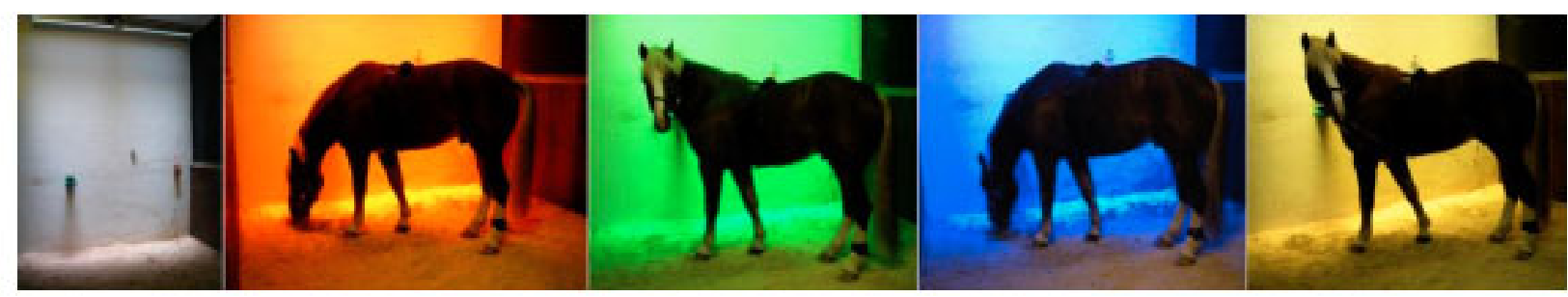

Fig. (2). Light-box with ceiling-mounted LED lights at white light and horse during illumination with red, green, blue and yellow light (from left to right).

\subsection{Data Recording}

For data analysis, only 14 min (minute 6 - 19) of each experimental phase (pre-, light-, and post-) were used accounting for adaption of the horse to the experimental box stalls.

\subsubsection{Behaviour}

Activity was recorded continuously by means of an ALT-Pedometer ${ }^{c}$ and stored as the sum of single step events per minute. The pedometer was attached to the horses' left hind leg above the fetlock. Data was transferred to a

\footnotetext{
${ }^{\mathrm{b}}$ LED lamp HEDERA, Zumtobel Licht AG, Zurich, Switzerland

${ }^{\mathrm{c}}$ ALT-Pedometer, Ingenieurbüro Holz, Falkenhagen, Germany
} 
computer using associated ALT-Pedometer-Software ${ }^{\mathrm{d}}$ and the mean steps per minute were calculated. Due to a problem with the logger capacity, data of 10 horses only was available for the analysis.

During the exposition to the coloured light, the horses were filmed, allowing real time observation out of sight of the animals via a monitor. Behavioural parameters and position (Table 2) within the light-box were recorded continuously using Interact $^{\mathbb{E} e}$. The frequency of defecation and urination was documented additionally in pre- and postphase by counting droppings and urine stains.

Table 2. Ethogram of observed behavioural parameters and position in the light-phase.

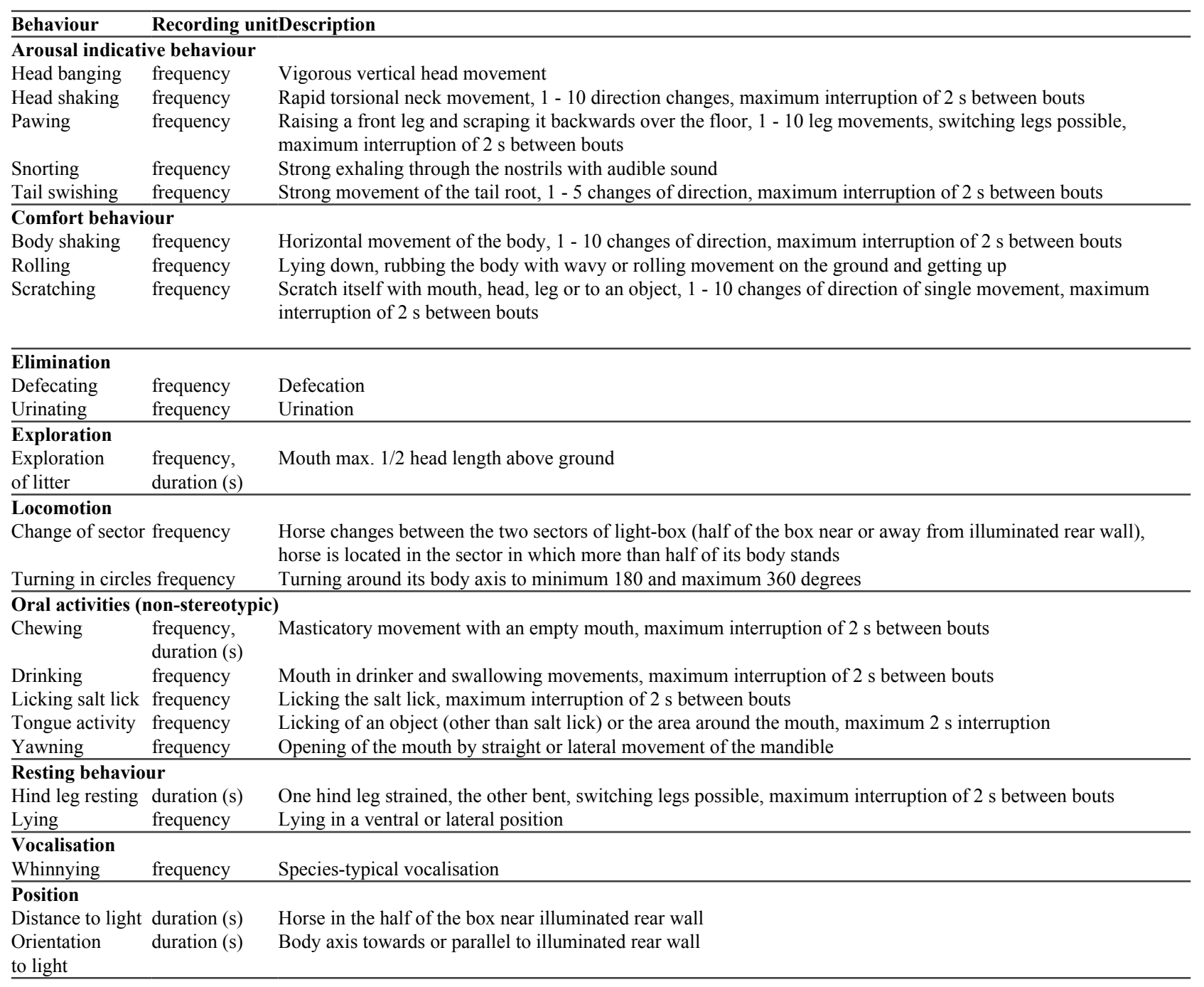

\subsubsection{Physiological Parameters}

Heart rate parameters were measured continuously with the Polar ${ }^{\circledR}$ heart rate monitoring system ${ }^{\mathrm{f}}$, using an elastic surcingle with two electrodes attached behind the fore legs aligned to position of saddle girth. Ultrasound gel was used to optimise the contact between electrodes and skin. The recorded data was readout with associated Polar ${ }^{\circledR}$ software $^{\mathrm{g}}$. Data was corrected for artefacts (filtration rate: moderate, minimal protection zone: 6) with the maximum acceptable value for identified errors set at $10 \%$. With this precondition, 51 incorrect measurements of in total 300 data points were

\footnotetext{
${ }^{\mathrm{d}}$ ALT-Pedometer-Software, Version 4.0.3.0, Ingenieurbüro Holz, Falkenhagen, Germany

${ }^{\mathrm{e}}$ Interact ${ }^{\mathbb{B}}$, Version 8.5.0, Mangold International GmbH, Arnstorf, Germany

${ }^{\mathrm{f}} \mathrm{Polar}^{\circledR}$ S810i watch, Polar Electro Europe, Zug, Switzerland

${ }^{\mathrm{g}}$ Polar ${ }^{\circledR}$ ProTrainer 5, Equine Edition, Version 5.35.161, Polar Electro Europe, Fleurier, Switzerland
} 
not included in the data analysis, excluding one horse completely. The mean heart rate and heart rate variability, measured as RMSSD (root mean square of successive beat-to-beat differences in milliseconds), were determined for each phase.

Body core and body surface temperature were measured after each experimental phase. Body core temperature was measured rectally using a thermometer ${ }^{\mathrm{h}}$; for each measurement time, three values were taken and averaged. Body surface temperature was measured using an infrared thermal camera ${ }^{i}$. After each phase, photos of the right and left side of the body were taken from a distance of about $6 \mathrm{~m}$. The pictures were analysed with associated IRwin OLE software'. Each photo was corrected for ambience temperature and atmospheric humidity at the time of photographing, using timematched stable climate data recorded by a weather station ${ }^{\mathrm{k}}$ placed in the barn. In each photo three areas on the horse were marked (1. trapezoid along the jugular groove to the base of the neck, up to the withers and back to the throat, 2. rectangle stretched between stifle and back, limited by the heart rate monitor girth, 3. rectangle stretched between stifle and dock) and the average temperature was determined for each area. Finally, the mean average surface temperature of the horse was calculated including all three areas of the left and right body side. The three horses that were wearing rugs outside the experimental procedure were not included in the analysis of body surface temperature.

Salivary cortisol levels were determined following the light-phase. Samples were taken by holding a cotton swab ${ }^{1}$ with a clamp and placing it in the mouth for about 15 seconds. The wadding was centrifuged (15 min, $3000 \mathrm{rpm})$ after experiments finished on a given day and afterwards deep-frozen $\left(-85^{\circ} \mathrm{C}\right)$ until analysis. Samples were analysed by the Laboratory of Veterinary-Physiology (Vetsuisse Faculty, University of Berne, Switzerland) by use of a Salimetrics ${ }^{\circledR}$ analysis $\mathrm{kit}^{\mathrm{m}}$. Analysis was performed according to the manufacturer [35] and results were expressed in $\mathrm{nmol} / \mathrm{ml}$.

\subsection{Statistical Analysis}

Statistical analysis was conducted in R (The R Project for Statistical Computing, Version 2.15.0 [36]) using generalised linear mixed-effects models; lme method (package 'nlme' [37]) and glmer method (package 'lme4' [38]). For parameters recorded only in the light-phase, explanatory variables included "colour" (factor with five levels: white, red, green, blue, yellow) as fixed effect and "animal nested within test week" as random effect. For parameters recorded in all phases of the test procedure (pre-, light-, post-phase), explanatory variables included "colour" (factor with five levels: white, red, green, blue, yellow), "phase" (factor with three levels: pre-, light-, post-phase) and their interaction "colour*phase" as fixed effects and "day nested within animal within test week" as random effect. Models with only main effects were compared to models additionally including the interaction of the main effects by means of Akaike information criterion (AIC values), in order to determine the best fitting model for each parameter. The models with the lower AIC values [39] were chosen as final models and presented as results; models with only the main effects were found to be the best fitting for all parameters.

The lme method was used with type I sum of squares to calculate the $p$-values for explanatory variables. Statistical assumptions of all models were checked using graphical analysis of residuals (normal distribution, homoscedasticity). To meet the statistical assumptions, some outliers were excluded (in maximum 7 data points per response variable) and some of the response variables were transformed (log-transformation for activity, heart rate parameters and body surface temperature, for behavioural parameters, see Table 3). If transformation was not successful to achieve normal distribution of residuals, the response variables were dichotomised and the glmer method was used (Table 3). For calculation of $p$-values with glmer method, maximum models were compared to minimum models (parameters observed only in light phase: models with fixed effect "colour" vs. models with no fixed effect; parameters observed in all three phases: models with fixed effects "colour" and "phase" vs. models with fixed effect "colour" or fixed effect "phase"). For some behavioural parameters, statistical analysis was not possible due to very low frequencies (Table 3).

While model selection was performed according to AIC values, $p$-values of main effects were presented in order to support understanding [40]. In addition, model predictions with estimated means and 95\% confidence intervals were

\footnotetext{
${ }^{\mathrm{h}}$ Microlife VT 1831 Vet-Temp, Microlife AG Swiss Corporation, Widnau, Switzerland

'ThermaCAM PM695, FLIR Systems GmbH, Frankfurt am Main, Germany

${ }^{\mathrm{j}}$ IRwin OLE, Version 1.1, AGEMA Infrared Systems, Danderyd, Sweden

${ }^{\mathrm{k}}$ Thermo-/ Hygrometer No. 7022.059, Melectronics, Zurich, Switzerland

${ }^{1}$ Salivette ${ }^{\mathbb{B}}$ No. 51.1534, Sarstedt AG and Co, Nümbrecht, Germany

${ }^{\mathrm{m}}$ Salimetrics ${ }^{\circledR}$ Salivary Cortisol Enzyme Immunoassay Kit No. 1-3002, Salimetrics Europe Ltd., Newmarket, United Kingdom
} 
calculated for every experimental situation ("colour" or combination of "colour" and "phase") on basis of the respective model and used for interpretation of the effects in case of statistically significant results.

\subsection{Ethical Approval}

Ethical approval for the implementation of the study was obtained from the Vaud Cantonal Veterinary Office, Switzerland (Approval No. 2265, 2009).

\section{RESULTS}

\subsection{Behaviour}

In comparison to white, "drinking" occurred more often at yellow $\left(\chi_{4}^{2}=14.62, p=0.0056\right.$; (Fig. 3). Colour did not affect any of the other behavioural parameters, the position (see Table 3), or activity $\left(\mathrm{F}_{4,36}=0.92, p=0.5\right.$; (Fig. 4). However, activity was decreased in the light-phase compared to the pre- and post-phase $\left(\mathrm{F}_{2,92}=5.39, p=0.0061\right.$; (Fig. 4), regardless of colour. Defecation was observed more often in the pre-phase compared to the subsequent phases, regardless of colour $\left(\chi_{4}^{2}=21.18, p=0.017\right.$; (Fig. 5)).

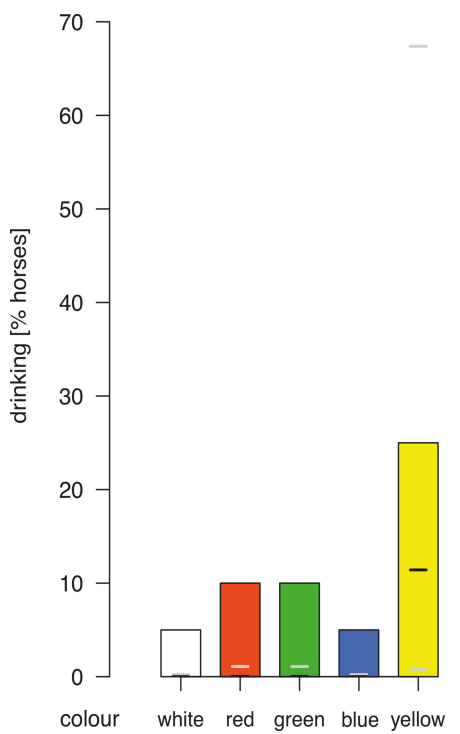

Fig. (3). Percentage of horses showing "drinking" in relation to colour, including model predictions with estimated means (black lines) and $95 \%$ confidence intervals (grey lines).

Table 3. Behavioural parameters and position observed in the light-box during illumination with different colours. Raw data given as means and ranges ( $\mathrm{min}$ - max) of recording unit (in brackets for parameters analysed as dichotomised variables) and percentage of horses $(n=20)$ showing the respective behaviours. Statistical results with selection of model (including eventual transformation for Ime method or distributional family for glmer method), statistical unit, test statistics and $p$-values $(<0.05$ in bold).

\begin{tabular}{|c|c|c|c|c|c|c|c|c|}
\hline & White & Red & Green & Blue & Yellow & & & \\
\hline $\begin{array}{l}\text { Behaviour } \\
\text { and } \\
\text { position } \\
\text { [recording } \\
\text { unit] }\end{array}$ & & & $\begin{array}{l}\varnothing ; \min -\max \\
\% \text { horses }\end{array}$ & & & $\begin{array}{l}\text { Model } \\
\text { [statistical unit] }\end{array}$ & test statistics & $p$-value \\
\hline $\begin{array}{l}\text { Head } \\
\text { banging } \\
\text { [frequency] }\end{array}$ & $\begin{array}{c}0.25 ; 0-4 \\
10 \%\end{array}$ & $\begin{array}{c}0.1 ; 0-1 \\
10 \%\end{array}$ & $\begin{array}{c}0 \\
0 \%\end{array}$ & $\begin{array}{c}0 \\
0 \%\end{array}$ & $\begin{array}{c}0.35 ; 0-7 \\
5 \%\end{array}$ & no statistics & & \\
\hline $\begin{array}{l}\text { Head } \\
\text { shaking } \\
\text { [frequency] }\end{array}$ & $\begin{array}{c}1.4 ; 0-5) \\
55 \%\end{array}$ & $\begin{array}{c}(1.95 ; 0-5) \\
70 \%\end{array}$ & $\begin{array}{c}(1.8 ; 0-9) \\
65 \%\end{array}$ & $\begin{array}{c}(1.25 ; 0-6) \\
50 \%\end{array}$ & $\begin{array}{c}(2.25 ; 0-20) \\
60 \%\end{array}$ & $\begin{array}{l}\text { glmer (binomial) } \\
\text { [incidence] }\end{array}$ & $x_{4}^{2}=2.52$ & $p=0.64$ \\
\hline $\begin{array}{l}\text { Pawing } \\
\text { [frequency] }\end{array}$ & $\begin{array}{c}(1.7 ; 0-9) \\
55 \%\end{array}$ & $\begin{array}{c}(3.75 ; 0-25) \\
45 \%\end{array}$ & $\begin{array}{c}(1.85 ; 0-22) \\
35 \%\end{array}$ & $\begin{array}{c}(0.9 ; 0-8) \\
30 \%\end{array}$ & $\begin{array}{c}(1.3 ; 0-10) \\
40 \%\end{array}$ & $\begin{array}{l}\text { glmer (binomial) } \\
\text { [incidence] }\end{array}$ & $\chi_{4}^{2}=3.64$ & $p=0.46$ \\
\hline $\begin{array}{l}\text { Snorting } \\
\text { [frequency] }\end{array}$ & $\begin{array}{c}(1.05 ; 0-5) \\
55 \%\end{array}$ & $\begin{array}{c}(0.95 ; 0-3) \\
55 \%\end{array}$ & $\begin{array}{c}(1.6 ; 0-9) \\
60 \%\end{array}$ & $\begin{array}{c}(0.9 ; 0-4) \\
65 \%\end{array}$ & $\begin{array}{c}(1.55 ; 0-6) \\
45 \%\end{array}$ & $\begin{array}{l}\text { glmer (binomial) } \\
\text { [incidence] }\end{array}$ & $\chi_{4}^{2}=1.95$ & $p=0.74$ \\
\hline
\end{tabular}




\begin{tabular}{|c|c|c|c|c|c|c|c|c|}
\hline & White & Red & Green & Blue & Yellow & & & \\
\hline $\begin{array}{l}\text { Behaviour } \\
\text { and } \\
\text { position } \\
\text { [recording } \\
\text { unit] }\end{array}$ & & & $\begin{array}{l}\varnothing ; \min -\max \\
\% \text { horses }\end{array}$ & & & $\begin{array}{l}\text { Model } \\
\text { [statistical unit] }\end{array}$ & test statistics & $p$-value \\
\hline Tail & 0 & 0 & $0.05 ; 0-1$ & $0.05 ; 0-1$ & 0 & no statistics & & \\
\hline $\begin{array}{l}\text { swishing } \\
\text { [frequency] }\end{array}$ & $0 \%$ & $0 \%$ & $5 \%$ & $5 \%$ & $0 \%$ & & & \\
\hline $\begin{array}{l}\text { Body } \\
\text { shaking } \\
\text { [frequency] }\end{array}$ & $\begin{array}{c}0 \\
0 \%\end{array}$ & $\begin{array}{c}0.05 ; 0-1 \\
5 \%\end{array}$ & $\begin{array}{c}0.05 ; 0-1 \\
5 \%\end{array}$ & $\begin{array}{c}0.05 ; 0-1 \\
5 \%\end{array}$ & $\begin{array}{c}0.2 ; 0-3 \\
10 \%\end{array}$ & no statistics & & \\
\hline $\begin{array}{l}\text { Rolling } \\
\text { frequency] }\end{array}$ & $\begin{array}{c}0 \\
0 \%\end{array}$ & $\begin{array}{c}0.05 ; 0-1 \\
5 \%\end{array}$ & $\begin{array}{c}0 \\
0 \%\end{array}$ & $\begin{array}{c}0 \\
0 \%\end{array}$ & $\begin{array}{c}0.05 ; 0-1 \\
5 \%\end{array}$ & no statistics & & \\
\hline $\begin{array}{l}\text { Scratching } \\
\text { [frequency] }\end{array}$ & $\begin{array}{c}(2.25 ; 0-14) \\
70 \%\end{array}$ & $\begin{array}{c}(1.6 ; 0-6) \\
55 \%\end{array}$ & $\begin{array}{c}(0.95 ; 0-7) \\
45 \%\end{array}$ & $\begin{array}{c}(1.8 ; 0-7) \\
60 \%\end{array}$ & $\begin{array}{c}(2.05 ; 0-10) \\
55 \%\end{array}$ & $\begin{array}{l}\text { glmer (binomial) } \\
\text { [incidence] }\end{array}$ & $\chi_{4}^{2}=2.84$ & $p=0.58$ \\
\hline $\begin{array}{l}\text { Defecating } \\
\text { [frequency] }\end{array}$ & $\begin{array}{c}(0.02 ; 0-1) \\
10 \%\end{array}$ & $\begin{array}{c}(0.04 ; 0-1) \\
20 \%\end{array}$ & $\begin{array}{c}(0.03 ; 0-1) \\
15 \%\end{array}$ & $\begin{array}{c}(0.05 ; 0-2) \\
15 \%\end{array}$ & $\begin{array}{c}(0.03 ; 0-1) \\
15 \%\end{array}$ & $\begin{array}{l}\text { glmer (binomial) } \\
\text { [incidence] }\end{array}$ & $\chi_{4}^{2}=5.36$ & $p=0.25$ \\
\hline $\begin{array}{l}\text { Urinating } \\
\text { [frequency] }\end{array}$ & $\begin{array}{c}0 \\
0 \%\end{array}$ & $\begin{array}{c}0 \\
0 \%\end{array}$ & $\begin{array}{c}0 \\
0 \%\end{array}$ & $\begin{array}{c}0 \\
0 \%\end{array}$ & $\begin{array}{c}0 \\
0 \%\end{array}$ & no statistics & & \\
\hline $\begin{array}{l}\text { Exploration } \\
\text { of litter } \\
\text { [frequency] }\end{array}$ & $\begin{array}{c}3.8 ; 0-16 \\
90 \%\end{array}$ & $\begin{array}{c}3.85 ; 0-16 \\
75 \%\end{array}$ & $\begin{array}{c}3.25 ; 0-11 \\
80 \%\end{array}$ & $\begin{array}{c}3.55 ; 0-15 \\
75 \%\end{array}$ & $\begin{array}{c}4.5 ; 0-17 \\
80 \%\end{array}$ & $\begin{array}{l}\text { lme (log) } \\
\text { [frequency] }\end{array}$ & $\mathrm{F}_{4,76}=0.26$ & $p=0.9$ \\
\hline $\begin{array}{l}\text { Exploration } \\
\text { of litter } \\
\text { [duration } \\
\text { (s)] }\end{array}$ & $\begin{array}{c}58.3 ; 0-212.9 \\
90 \%\end{array}$ & $\begin{array}{c}56.6 ; 0-233.5 \\
75 \%\end{array}$ & $\begin{array}{c}59.4 ; 0-301.3 \\
80 \%\end{array}$ & $\begin{array}{c}50.5 ; 0-187.1 \\
75 \%\end{array}$ & $\begin{array}{c}53.2 ; 0-336.0 \\
80 \%\end{array}$ & $\begin{array}{l}0 \operatorname{lme}(\log ) \\
\text { [duration (s)] }\end{array}$ & $\mathrm{F}_{4,76}=0.19$ & $p=0.95$ \\
\hline $\begin{array}{l}\text { Change of } \\
\text { sector } \\
\text { [frequency] }\end{array}$ & $\begin{array}{c}8.1 ; 0-36 \\
85 \%\end{array}$ & $\begin{array}{c}8.7 ; 0-26 \\
80 \%\end{array}$ & $\begin{array}{c}6.15 ; 0-18 \\
80 \%\end{array}$ & $\begin{array}{c}6.6 ; 0-17 \\
80 \%\end{array}$ & $\begin{array}{c}8.9 ; 0-32 \\
75 \%\end{array}$ & $\begin{array}{l}\text { lme (sqrt) } \\
\text { [frequency] }\end{array}$ & $\mathrm{F}_{4,76}=0.26$ & $p=0.9$ \\
\hline $\begin{array}{l}\text { Turning in } \\
\text { circles } \\
\text { [frequency] }\end{array}$ & $\begin{array}{c}(0.3 ; 0-2) \\
20 \%\end{array}$ & $\begin{array}{c}(0.7 ; 0-5) \\
30 \%\end{array}$ & $\begin{array}{c}(1 ; 0-8) \\
25 \%\end{array}$ & $\begin{array}{c}(0.5 ; 0-4) \\
30 \%\end{array}$ & $\begin{array}{c}(0.65 ; 0-4) \\
40 \%\end{array}$ & $\begin{array}{l}\text { glmer (binomial) } \\
\text { [incidence] }\end{array}$ & $\chi_{4}^{2}=3.30$ & $p=0.51$ \\
\hline $\begin{array}{l}\text { Chewing } \\
\text { [frequency] }\end{array}$ & $\begin{array}{c}4.3 ; 0-12 \\
90 \%\end{array}$ & $\begin{array}{c}5.3 ; 0-15 \\
90 \%\end{array}$ & $\begin{array}{c}6.35 ; 0-22 \\
90 \%\end{array}$ & $\begin{array}{c}6.85 ; 2-20 \\
100 \%\end{array}$ & $\begin{array}{c}6.9 ; 0-20 \\
90 \%\end{array}$ & $\begin{array}{l}\text { lme } \\
\text { [frequency] }\end{array}$ & $\mathrm{F}_{4,74}=1.12$ & $p=0.36$ \\
\hline $\begin{array}{l}\text { Chewing } \\
\text { [duration } \\
\text { (s)] }\end{array}$ & $\begin{array}{c}28.3 ; 0-94.2 \\
90 \%\end{array}$ & $\begin{array}{c}36.8 ; 0-185.4 \\
90 \%\end{array}$ & $\begin{array}{c}46.5 ; 0-163.0 \\
90 \%\end{array}$ & $\begin{array}{c}46.7 ; 10.2-136.9 \\
100 \%\end{array}$ & $\begin{array}{c}39.5 ; 0-101.6 \\
90 \%\end{array}$ & 5 lme & $\mathrm{F}_{4,73}=1.5$ & $p=0.21$ \\
\hline $\begin{array}{l}\text { Drinking } \\
\text { [frequency] }\end{array}$ & $\begin{array}{c}(0.05 ; 0-1) \\
5 \%\end{array}$ & $\begin{array}{c}(0.1 ; 0-1) \\
10 \%\end{array}$ & $\begin{array}{c}(0.1 ; 0-1) \\
10 \%\end{array}$ & $\begin{array}{c}(0.05 ; 0-1) \\
5 \%\end{array}$ & $\begin{array}{c}(0.25 ; 0-1) \\
25 \%\end{array}$ & $\begin{array}{l}\text { glmer (binomial) } \\
\text { [incidence] }\end{array}$ & $\chi_{4}^{2}=14.62$ & $p=0.0056$ \\
\hline $\begin{array}{l}\text { Licking } \\
\text { salt lick } \\
\text { [frequency] }\end{array}$ & $\begin{array}{c}(0.3 ; 0-3) \\
20 \%\end{array}$ & $\begin{array}{c}(0.15 ; 0-2) \\
10 \%\end{array}$ & $\begin{array}{c}(0.45 ; 0-3) \\
20 \%\end{array}$ & $\begin{array}{c}(0.35 ; 0-4) \\
10 \%\end{array}$ & $\begin{array}{c}(0.4 ; 0-3) \\
20 \%\end{array}$ & $\begin{array}{l}\text { glmer (binomial) } \\
\text { [incidence] }\end{array}$ & $\chi_{4}^{2}=2.36$ & $p=0.67$ \\
\hline $\begin{array}{l}\text { Tongue } \\
\text { activity } \\
\text { [frequency] }\end{array}$ & $\begin{array}{c}(0.55 ; 0-5) \\
20 \%\end{array}$ & $\begin{array}{c}(0.15 ; 0-1) \\
15 \%\end{array}$ & $\begin{array}{c}(0.45 ; 0-2) \\
30 \%\end{array}$ & $\begin{array}{c}(0.45 ; 0-6) \\
20 \%\end{array}$ & $\begin{array}{c}(0.8 ; 0-4 \\
40 \%)\end{array}$ & $\begin{array}{l}\text { glmer (binomial) } \\
\text { [incidence] }\end{array}$ & $\chi_{4}^{2}=4.63$ & $p=0.33$ \\
\hline $\begin{array}{l}\text { Yawning } \\
\text { [frequency] }\end{array}$ & $\begin{array}{c}1.2 ; 0-7 \\
40 \% \\
\end{array}$ & $\begin{array}{c}1.85 ; 0-12 \\
45 \%\end{array}$ & $\begin{array}{c}2 ; 0-10 \\
55 \%\end{array}$ & $\begin{array}{c}1.45 ; 0-4 \\
55 \%\end{array}$ & $\begin{array}{c}1.7 ; 0-7 \\
40 \%\end{array}$ & $\begin{array}{l}\text { glmer (binomial) } \\
\text { [incidence] }\end{array}$ & $\chi_{4}^{2}=2.60$ & $p=0.63$ \\
\hline $\begin{array}{l}\text { Hind leg } \\
\text { resting } \\
\text { [duration } \\
\text { (s)] }\end{array}$ & $\begin{array}{c}65.88 ; 0-100 \\
95 \%\end{array}$ & $\begin{array}{c}63.29 ; 1.8-100 \\
100 \%\end{array}$ & $\begin{array}{c}69.4 ; 13.9-100 \\
100 \%\end{array}$ & $\begin{array}{c}66.17 ; 18.5-99.8 \\
100 \%\end{array}$ & $\begin{array}{c}64.01 ; 0-100 \\
90 \%\end{array}$ & $\begin{array}{l}\text { lme (logit) } \\
{[\% \text { of time }]}\end{array}$ & $\mathrm{F}_{4,73}=0.55$ & $p=0.7$ \\
\hline $\begin{array}{l}\text { Lying } \\
\text { [frequency] }\end{array}$ & $\begin{array}{c}0.05 ; 0-1 \\
5 \%\end{array}$ & $\begin{array}{c}0 \\
0 \%\end{array}$ & $\begin{array}{c}0 \\
0 \%\end{array}$ & $\begin{array}{c}0 \\
0 \%\end{array}$ & $\begin{array}{c}0 \\
0 \%\end{array}$ & no statistics & & \\
\hline $\begin{array}{l}\text { Whinnying } \\
\text { [frequency] }\end{array}$ & $\begin{array}{c}0 \\
0 \%\end{array}$ & $\begin{array}{c}0.05: 0-1 \\
5 \%\end{array}$ & $\begin{array}{c}0 \\
0 \%\end{array}$ & $\begin{array}{c}0 \\
0 \%\end{array}$ & $\begin{array}{c}0 \\
0 \%\end{array}$ & no statistics & & \\
\hline $\begin{array}{l}\text { Distance to } \\
\text { light } \\
\text { [duration } \\
\text { (s)] }\end{array}$ & $\begin{array}{c}35.39 ; 0-100 \\
85 \%\end{array}$ & $\begin{array}{c}26.82 ; 0-94.4 \\
75 \%\end{array}$ & $\begin{array}{c}35.44 ; 0-100 \\
85 \%\end{array}$ & $\begin{array}{c}37.25 ; 0-100 \\
80 \%\end{array}$ & $\begin{array}{c}44.33 ; 0-100 \\
75 \%\end{array}$ & $\begin{array}{l}\text { lme (logit) } \\
{[\% \text { of time }]}\end{array}$ & $\mathrm{F}_{4,76}=0.53$ & $p=0.72$ \\
\hline $\begin{array}{l}\text { Orientation } \\
\text { to light } \\
\text { [duration } \\
\text { (s)] }\end{array}$ & $\begin{array}{c}23.99 ; 0-100 \\
95 \%\end{array}$ & $\begin{array}{c}27.05 ; 0-100 \\
75 \%\end{array}$ & $\begin{array}{c}27.58 ; 0-100 \\
85 \%\end{array}$ & $\begin{array}{c}25.96 ; 0-98.4 \\
80 \%\end{array}$ & $\begin{array}{c}13.17 ; 0-100 \\
75 \%\end{array}$ & $\begin{array}{l}\text { lme (logit) } \\
{[\% \text { of time] }}\end{array}$ & $\mathrm{F}_{4,76}=0.48$ & $p=0.75$ \\
\hline
\end{tabular}




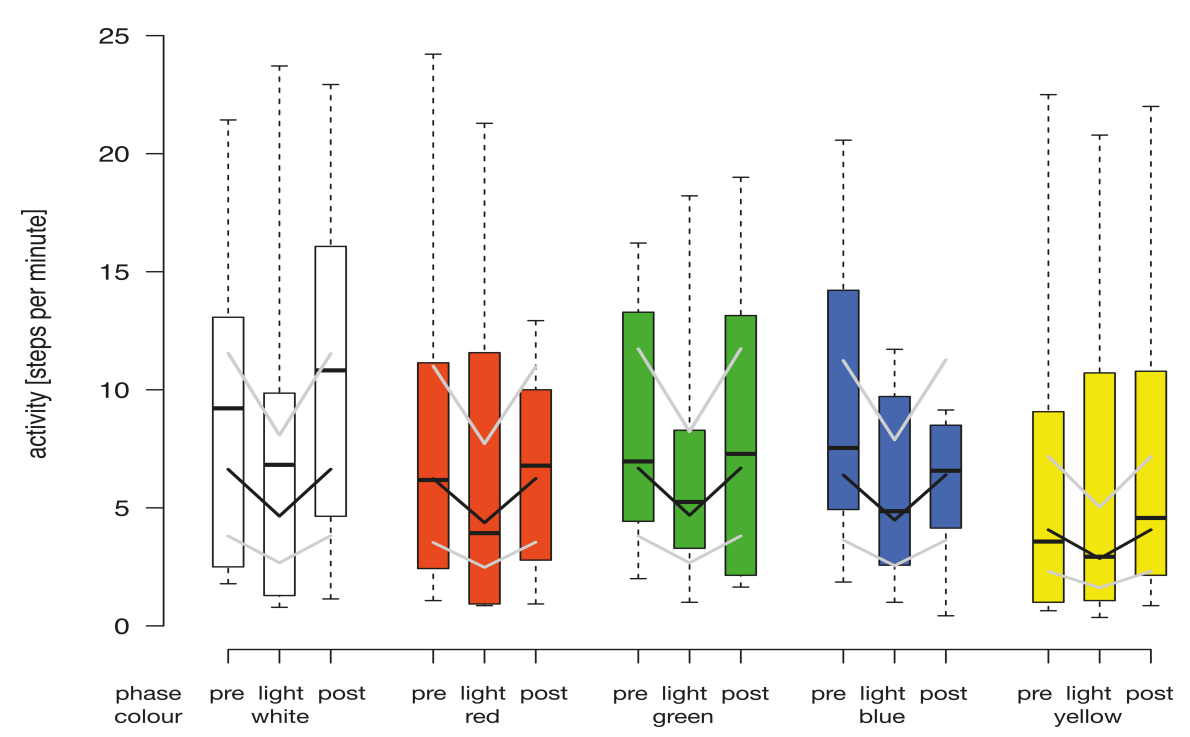

Fig. (4). Activity [steps per minute] in relation to colour and experimental phase (pre-, light-, post-phase). Raw data are given as boxplots with medians, interquartile and absolute ranges, in addition to model predictions with estimated means (black lines) and $95 \%$ confidence intervals (grey lines).

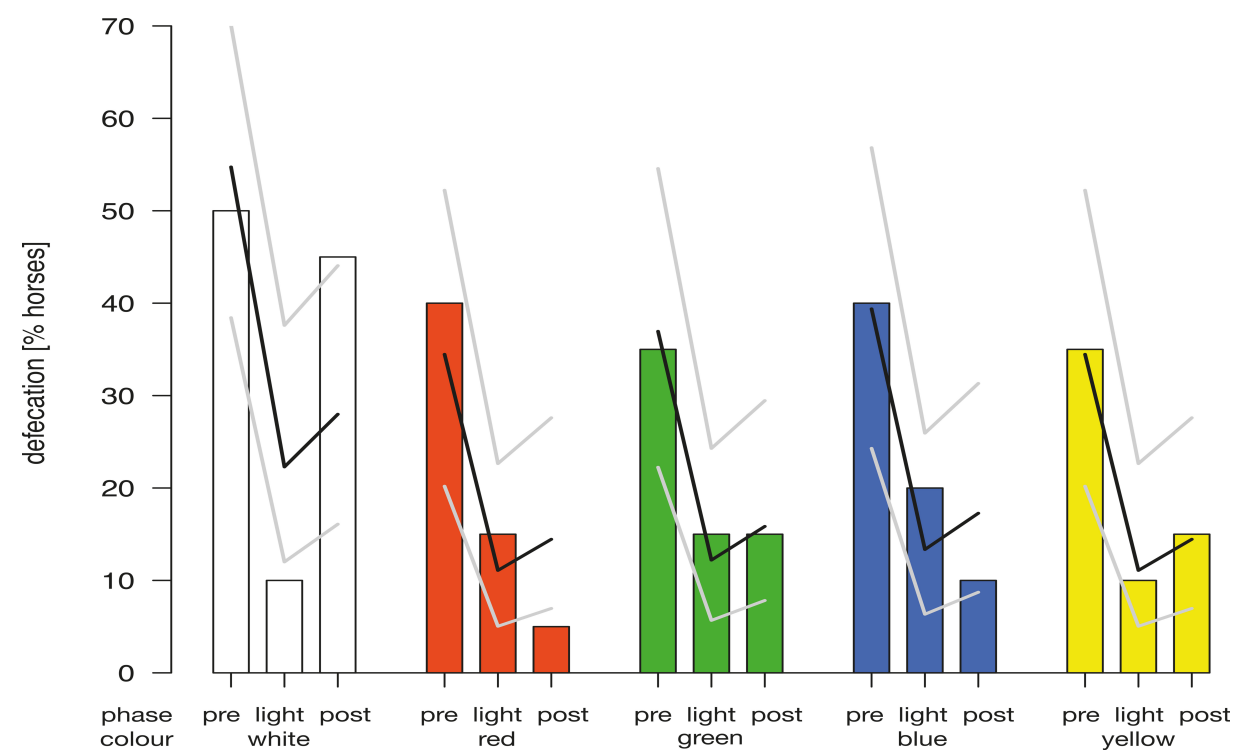

Fig. (5). Percentage of horses showing "defecation" in relation to colour and experimental phase (pre-, light-, post-phase), including model predictions with estimated means (black lines) and 95\% confidence intervals (grey lines).

\subsection{Physiological Parameters}

No significant effect of colour was found on heart rate $\left(\mathrm{F}_{4,68}=0.36, p=0.8\right.$; (Fig. 6)) or heart rate variability (RMSSD; $\mathrm{F}_{4,69}=0.5, p=0.7$; (Fig. 6)). However, compared to the pre-phase, heart rate was decreased in the light-phase and returned to pre-phase level in the post-phase $\left(\mathrm{F}_{2,147}=8.54, p=0.0003\right.$; (Fig. 6)). The heart rate variability remained at pre-phase level in the light-phase but increased in the post-phase $\left(\mathrm{F}_{2,148}=7.54, p=0.0008\right.$; (Fig. 6)). In comparison to white, body core temperature was increased at red and blue and decreased at green and yellow $\left(\mathrm{F}_{4,76}=2.5 p=0.048\right.$; (Fig. 7)). A general decrease in body core temperature was recorded over the course of test procedure, regardless of colour $\left(\mathrm{F}_{2,193}=8.5, p=0.0003\right.$; (Fig. 7)). The body surface temperature, however, tended to be increased at red, green, blue and yellow in comparison to white $\left(\mathrm{F}_{4,63}=2.3, p=0.069\right.$; (Fig. 7)) but generally decreased at the end of the lightphase, before increasing slightly after the post-phase $\left(\mathrm{F}_{2,163}=12.4, p<0.0001\right.$; (Fig. 7)). Colour had no effect on cortisol levels $\left(\mathrm{F}_{4,75}=0.67, p=0.6\right)$; mean salivary cortisol concentration after the light-phase was $1.14 \pm 0.6 \mathrm{nmol} / \mathrm{L}$. 

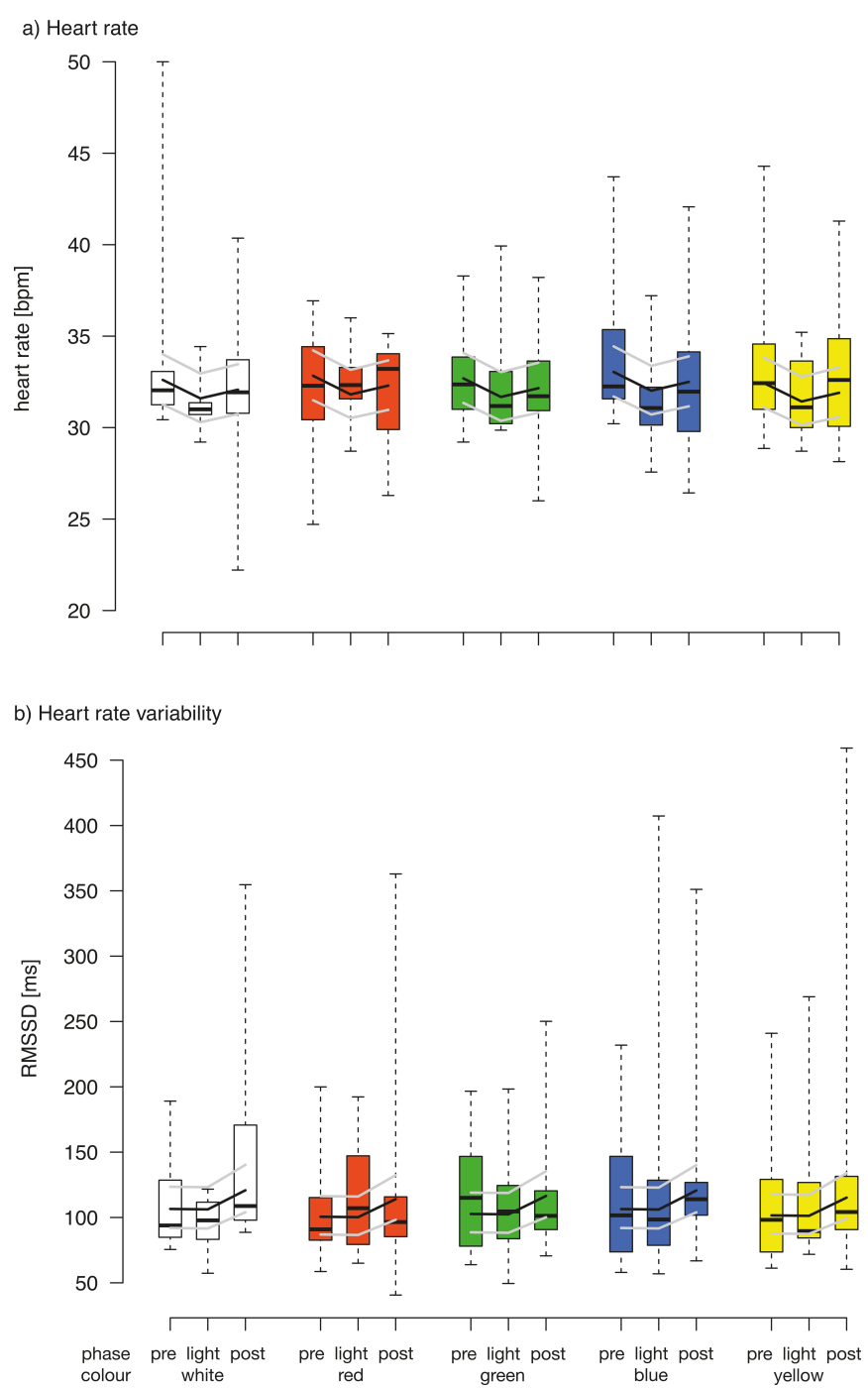

Fig. (6). a) Heart rate [beats per min] and b) Heart rate variability as RMSSD [ms] in relation to colour and experimental phase (pre-, light-, post-phase). Raw data are given as boxplots with medians, interquartile and absolute ranges, in addition to model predictions with estimated means (black lines) and 95\% confidence intervals (grey lines).

\section{DISCUSSION}

The selection of behavioural and physiological variables was sought to assess the variety of possible responses to coloured light under standardised conditions. An effect of coloured light was found on "drinking" as well as body core and body surface temperature. However, the obtained results were often not consistent with the literature on colour light therapy and, furthermore, no effect was found on many parameters, even though clearly described in literature. Red is described to be generally stimulating in horses [7], leading to an increaed heart rate, elevated blood circulation and inducing a warming effect [9]. Based thereon, effects regarding enhanced activity, cortisol levels, heart rate, and temperature parameters were expected. However, the results showed only an increase in body core and surface temperature, which was consistent with the postulated warming effect. Blue is described to generally have a calming and relaxing effect on horses [7]. Expectations regarding reduced activity and heart rate were not met. Furthermore, blue is used for treatment of diarrhoea, colic and costiveness due to stimulation of the parasympathetic nervous system $[7,10]$ wherefore effects on "defecating" and heart rate variability were expected; however, no effects were found in this study. Blue is also designated to have a blood circulation reducing effect which is used for treatment of fever [7]; results obtained in this study somehow refuted this by showing an increase in body core and surface temperature. Green is associated with the induction of general relaxation in horses [7] which has a balancing effect on the cardiovascular system and is commonly referred to as being a colour with an anti-inflammatory effect [9]. Expected effects were a reduction in activity and heart rate, whereas results did not correspond. Furthermore, the illumination with green caused 

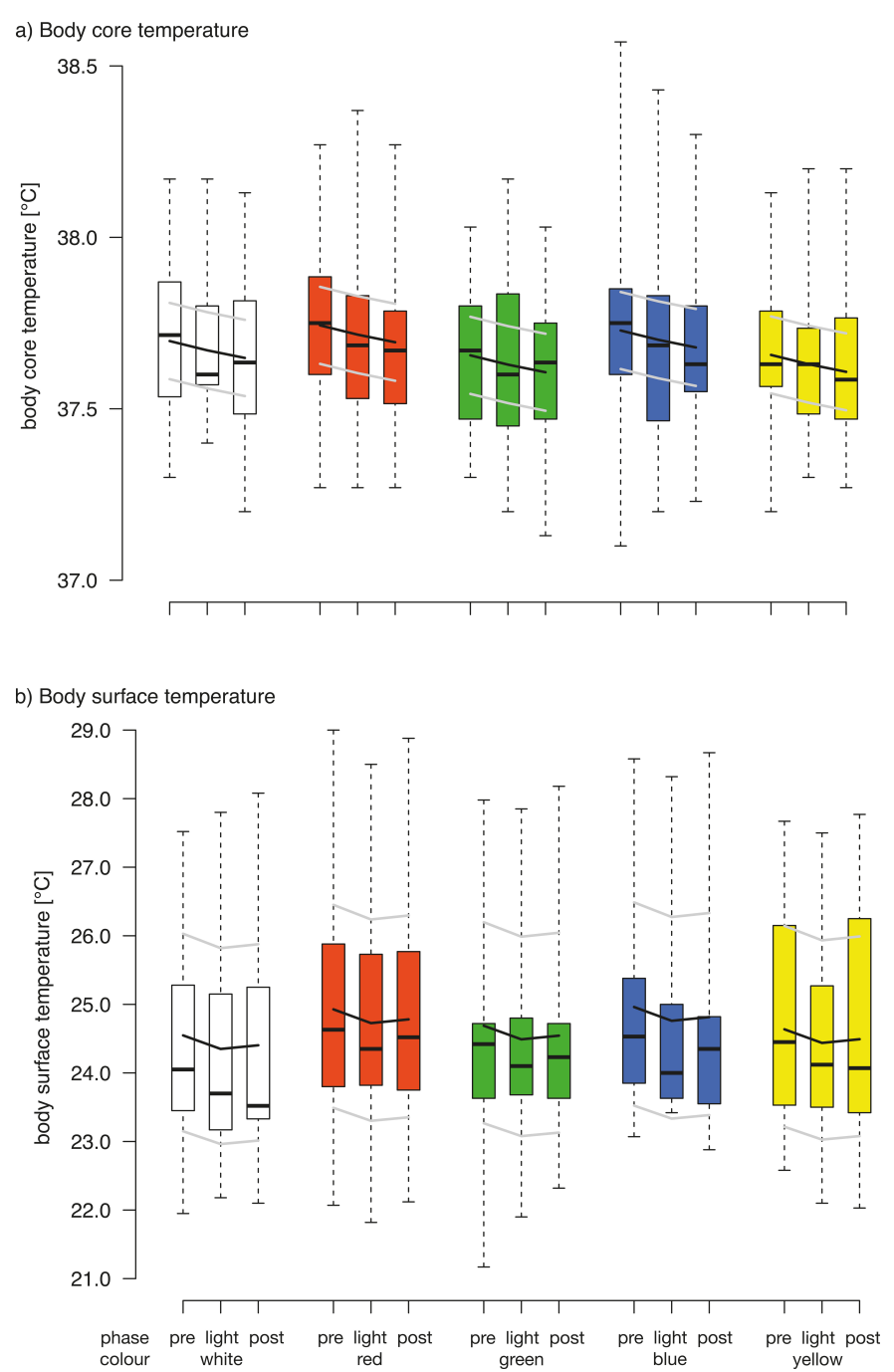

Fig. (7). a) Body core temperature $\left[{ }^{\circ} \mathrm{C}\right]$ and b) Body surface temperature $\left[{ }^{\circ} \mathrm{C}\right]$ in relation to colour and experimental phase (pre-, light-, post-phase) measured subsequent to the respective phase. Raw data are given as boxplots with medians, interquartile and absolute ranges, in addition to model predictions with estimated means (black lines) and 95\% confidence intervals (grey lines).

a decrease in body core temperature and an increase in body surface temperature, although literature did not describe any explicit effects. Assuming that colours should have had a similar effect on both parameters, the obtained results showed inverse effects which cannot be explained. For yellow, Muths [10] described a stimulating effect on nerves which can lead to increased activity or nervousness, but no effect on activity was found in this study. "Drinking" occurred more often at yellow, whereas no explicit statements about water intake were found in literature. Furthermore, body core and surface temperature decreased, although yellow is considered to be a stimulating and "hot colour" [9], for which reason an increase of body core temperature was expected.

The expected effects were based on results of research in humans or experiences of horse colour light therapists. Yet, obtained results were often inconsistent with expectations. Since the coloured light, type and duration of illumination used were consistent with practical therapy application, a variety of factors might have caused differing results. This study was conducted with healthy horses, whereas animals with specific disorders or diseases are treated in colour light therapy. Healthy horses may be affected to a lesser extent or not at all. Different coat thickness or coat colour could have influenced the mechanism of stimulation of photoreceptors in skin cells [23, 24]. However, practical colour light therapy is applied independently of season and no references on changing effectiveness by coat thickness or coat colour were found. In general, no statements can be made on the emphasis of impact on the eyes compared to impact on skin cells, as the illumination of the light-box probably acted through both mechanisms. Nevertheless, the experimental test procedure might has affected some parameters (e.g. activity, heart rate or heart rate variability), but the extent of interference cannot be assessed. Although handling before and between experimental phases was kept to a 
necessary minimum, it cannot be excluded that the horses were being disturbed and possible effects of coloured light were covered. The same applied for the alternation of experimental box stalls. However, experimental box stalls were next to each other and very similar to habitual box stalls. Furthermore, the test procedure was carried out in a similar way for every colour and the randomised order of colours should have accounted for possible effect of habituation with progressive test days. Another possible explanation for inconsistencies between expected effects and obtained results might be based on basically differing effects of colours on humans and horses. Humans learn physiologically determined effects of colours at an early stage of life [41]; red embodies such as "caution" or "heat", blue usually represents "coldness". Animals, on the other hand, need to respond very quickly to colour stimuli in nature and these reactions are often congenital [41]. In view of this, certain colour stimuli in natural environment may have different meanings for horses than for humans, wherefore principles deriving from light therapy in humans cannot be applied directly onto horses. As a further aspect, the effects of colours in light therapy could be mediated by the person applying the light. It has been shown repeatedly, that humans are able to transfer expectations to horses; Hama et al. [42] showed that humans with a negative attitude towards a horse caused an increase in heart rate only by stroking the horses' neck and Bridgeman and Pretty [43] found a correlation of the riders' and horses' heart rate during dressage exercise. Chamove et al. [44] also described that a horse owners attitude regarding an obstacle course correlated with the actual reactions of their horse. Thus a person, i.e. a colour light therapist and/or horse owner, must be considered as a direct confounding factor on the horse during application of colour light therapy. In the present study, however, light was applied without the presence of a person during illumination, wherefore this influence should have been eliminated and the reactions of the horses should correspond exclusively to the respective effects of the colours on the horses.

An effect of the experimental phase, regardless of colour, was apprehended for all parameters recorded in multiple phases. "Defecating" appeared more frequently in the pre-phase than in subsequent phases. It is less likely that this result was caused by a direct reaction to the initial experimental preparation as a sign of alertness, as Rietmann et al. [45] or Fureix et al. [46] recorded low defecation rates during mental handling stress tests. However, defecation was probably caused by elimination marking behaviour in stallions [47, 48]. Values of body core temperature were within the physiological range [49] but a general decrease was recorded across experimental phases. An effect of the stable climate $\left(\min / \max : 4.5 / 14.6^{\circ} \mathrm{C}\right)$ can be ruled out, as Cross et al. [50] substantiated that ambient temperatures within a range of $5-30{ }^{\circ} \mathrm{C}$ have no effect on body core temperature in horses. An influence of the circadian rhythm of the body core temperature can further be excluded; according to Green et al. [51] the minimum occurs in the morning and the maximum is reached in the evening. The experimental animals were tested between 09:00 and 16:00, therefore, body core temperature should have increased with subsequent phases. A possible explanation might be the correlation of activity and body core temperature due to physiological regulatory circuits [52]. Accordingly, the generally low activity in the experimental box stalls could have led to a decrease of body core temperature. The same interpretation can be made for the decrease of body surface temperature in the course of treatment. Including only horses with winter coat in the statistical analysis, the horses' body surface was not only well insulated but also well adapted to the ambient climate. For this reason, the experimental treatment itself should not have led to a change in heat production. Submitting that colours should have had a similar effect on body core and surface temperature, inverse effects at green and yellow cannot be explained. Activity during treatment was generally low and the horses were less active in the light-phase compared to both the pre- and post-phase. Locomotion is described in association with arousal [53]; consequently, the horses appeared to be not aroused in experimental box stalls and results suggested that illumination with coloured light had an activity-lowering effect. This assumption is supported by the results of "hind leg resting", which was averagely shown for over $60 \%$ of the time during illumination; a behaviour which is known to indicate a relaxed position during resting in standing position [54]. Similar to activity, heart rate was decreased in the light-phase compared to the pre-phase and post-phase. However, the heart rate of the experimental animals was mainly in range of heart rate at rest $[46,55]$ in all three phases. The horses' heart rate variability also ranged mainly within basal values of parasympathetic activity $[56,57]$ in all three phases. Compared to the pre- and light-phase, however, the RMSSD was increased in the post-phase, indicating a stronger parasympathetic influence $[29,58]$. Altogether, the decrease in heart rate without a change in heart rate variability during illumination may reflect a decreased sympathetic influence without activation of the parasympathetic branch. However, a more detailed analysis of heart rate variability may be necessary to enlighten the interactive effect of the sympatho-vagal activity during and after the illumination with coloured LED light in healthy horses.

In conclusion, there was no indication that either the treatment itself or the illumination with coloured light caused stress in the animals; a conclusion which is confirmed by levels of salivary cortisol ranging within basal concentration [59 - 61]. Noting that light plays an important role in the control of biological and physiological mechanisms [62], it can 
be assumed that the illumination, regardless of colour, had a generally becalming effect on the horses.

\section{CONCLUSION}

The present study showed an effect of coloured light on one behavioural parameter as well as the body core and surface temperature. For the majority of parameters, however, no effects were found and discovered effects often did not correspond with the expectations deriving from the principles of colour light therapy. A general effect of the illumination, regardless of the colour, was further demonstrated for activity and heart rate parameters, indicating a decreased sympathetic influence during and an increased parasympathetic influence after the illumination. Values of physiological parameters were generally within basal ranges. Considering the low activity and the fact that only a small minority of observed behaviours were affected, the illumination with coloured light seemed to be not stressful for the horses, but rather had a generally becalming effect. The application of coloured light, however, needs verification by further research, wherefore horses with described disorders and diseases should be examined before, during and after colour light therapy.

\section{LIST OF ABBREVIATIONS}

$\begin{array}{lll}\text { LED } & = & \text { Light-Emitting Diode } \\ \text { RMSSD } & = & \text { Root Mean Square of Successive Beat-to-Beat Differences }\end{array}$

\section{CONFLICT OF INTEREST}

The authors confirm that this article content has no conflict of interest.

\section{ACKNOWLEDGEMENTS}

The authors wish to thank the Swiss National Stud Farm (Agroscope, Switzerland) for providing their horses, stables and work as well as Dr. Dominik Burger and his team at the clinic (Swiss Institute of Equine Medicine ISME, Switzerland) for handling the cortisol samples. We appreciate the loan of the infrared thermal camera from Dr. Michael Weishaupt (Vetsuisse Faculty of University Zürich, Switzerland) and the loan of the ALT-Pedometers from Dr. Sandra Rose-Meierhöfer (Leibnitz Institute for Agricultural Engineering Postdam-Bornim e.V., Germany). We thank Dr. Jan Langbein (Leibniz-Institut für Nutztierbiologie FBN Dummer, Germany), PD Dr. Lorenz Gygax and Dr. Nina Keil (Centre for Proper Housing of Ruminants and Pigs, Federal Food Safety and Veterinary Office FSVO, Switzerland) for their contribution to the interpretation of the heart rate analysis and are especially grateful to PD Dr. Lorenz Gygax (Centre for Proper Housing of Ruminants and Pigs, Federal Food Safety and Veterinary Office FSVO, Switzerland) for his support during the statistical analysis.

\section{REFERENCES}

[1] Adamskaya N, Dungel P, Mittermayr R, et al. Light therapy by blue LED improves wound healing in an excision model in rats. Injury 2011; 42(9): 917-21.

[http://dx.doi.org/10.1016/j.injury.2010.03.023] [PMID: 22081819]

[2] Whinfield AL, Aitkenhead I. The light revival: does phototherapy promote wound healing? A review. The Foot 2009; $19(2)$ : 117-24. [http://dx.doi.org/10.1016/j.foot.2009.01.004] [PMID: 20307462]

[3] Oshima Y, Coutts RD, Badlani NM, Healey RM, Kubo T, Amiel D. Effect of light-emitting diode (LED) therapy on the development of osteoarthritis (OA) in a rabbit model. Biomed Pharmacother 2011; 65(3): 224-9. [http://dx.doi.org/10.1016/j.biopha.2011.02.011] [PMID: 21658899]

[4] Lapchak PA, Salgado KF, Chao CH, Zivin JA. Transcranial near-infrared light therapy improves motor function following embolic strokes in rabbits: an extended therapeutic window study using continuous and pulse frequency delivery modes. Neuroscience 2007; 148(4): 907-14. [http://dx.doi.org/10.1016/j.neuroscience.2007.07.002] [PMID: 17693028]

[5] Kronfeld-Schor N, Einat H. Circadian rhythms and depression: human psychopathology and animal models. Neuropharmacology 2012; 62(1): 101-14.

[http://dx.doi.org/10.1016/j.neuropharm.2011.08.020] [PMID: 21871466]

[6] Lim J, Sanders RA, Snyder AC, Eells JT, Henshel DS, Watkins JB III. Effects of low-level light therapy on streptozotocin-induced diabetic kidney. J Photochem Photobiol B 2010; 99(2): 105-10.

[7] Mahlstedt D. Farblichttherapie für Pferde, Praxis der Farbpunktur. 1st ed. Stuttgart, Germany: Sonntag Verlag, Medizinverlage Stuttgart GmbH and Co. KG 2004.

[8] Mandel P. Praktisches Handbuch der Farbpunktur. 6th ed. Bruchsal, Germany: Energetik-Verlag 1995. 
[9] Sonnenschmidt R. Farb- und Musiktherapie für Tiere. 1st ed. Stuttgart, Germany: Sonntag Verlag 2000.

[10] Muths C. Farbtherapie: Mit Farben heilen, der sanfte Weg zur Gesundheit. 6th ed. Munich, Germany: Wilhelm Heyne Verlag GmbH and Co. KG 1989.

[11] Barolet D. Light-emitting diodes (LEDs) in dermatology. Semin Cutan Med Surg 2008; 27(4): 227-38. [http://dx.doi.org/10.1016/j.sder.2008.08.003] [PMID: 19150294]

[12] Glickman G, Byrne B, Pineda C, Hauck WW, Brainard GC. Light therapy for seasonal affective disorder with blue narrow-band lightemitting diodes (LEDs). Biol Psychiatry 2006; 59(6): 502-7. [http://dx.doi.org/10.1016/j.biopsych.2005.07.006] [PMID: 16165105]

[13] Sisson TR, Kendall N, Glauser SC, Knutson S, Bunyaviroch E. Phototherapy of jaundice in newborn infant. I. ABO blood group incompatibility. J Pediatr 1971; 79(6): 904-10. [http://dx.doi.org/10.1016/S0022-3476(71)80182-8] [PMID: 5132302]

[14] Vreman HJ, Wong RJ, Stevenson DK. Phototherapy: current methods and future directions. Semin Perinatol 2004; $28(5)$ : $326-33$. [http://dx.doi.org/10.1053/j.semperi.2004.09.003] [PMID: 15686263]

[15] Terman M. Evolving applications of light therapy. Sleep Med Rev 2007; 11(6): 497-507. [http://dx.doi.org/10.1016/j.smrv.2007.06.003] [PMID: 17964200]

[16] İyilikci O, Aydin E, Canbeyli R. Blue but not red light stimulation in the dark has antidepressant effect in behavioral despair. Behav Brain Res 2009; 203(1): 65-8. [http://dx.doi.org/10.1016/j.bbr.2009.04.013] [PMID: 19379775]

[17] Weinzirl J, Wolf M, Heusser P, Wolf U. Colour therapy changes blood oxygenation in the brain and muscle. Eur J Integr Med 2009; 1(4): 198.

[http://dx.doi.org/10.1016/j.eujim.2009.08.110]

[18] Trimmer PA, Schwartz KM, Borland MK, De Taboada L, Streeter J, Oron U. Reduced axonal transport in Parkinson's disease cybrid neurites is restored by light therapy. Mol Neurodegener 2009; 4(1): 26. [http://dx.doi.org/10.1186/1750-1326-4-26] [PMID: 19534794]

[19] Trommershäuser J, Glimcher PW, Gegenfurtner KR. Visual processing, learning and feedback in the primate eye movement system. Trends Neurosci 2009; 32(11): 583-90.

[http://dx.doi.org/10.1016/j.tins.2009.07.004] [PMID: 19729211]

[20] Pick DF, Lovell GB, Dail D. Equine colour perception revisited. Appl Anim Behav Sci 1994; 42(1): 61-5. [http://dx.doi.org/10.1016/0168-1591(94)90007-8]

[21] Blackmore TL, Foster TM, Sumpter CE, Temple W. An investigation of colour discrimination with horses (Equus caballus). Behav Processes 2008; 78(3): 387-96.

[http://dx.doi.org/10.1016/j.beproc.2008.02.003] [PMID: 18359171]

[22] Smith S, Goldman L. Colour discrimination in horses. Appl Anim Behav 1999; 62(1): 13-25. [http://dx.doi.org/10.1016/S0168-1591(98)00206-8]

[23] Cohen S, Popp FA. Biophoton emission of the human body. J Photochem Photobiol B: 1997; 40(2): 187-9. [http://dx.doi.org/10.1016/S1011-1344(97)00050-X]

[24] Wurtman RJ. The effects of light on the human body. Sci Am 1975; 233(1): 69-77. [http://dx.doi.org/10.1038/scientificamerican0775-68] [PMID: 1145170]

[25] Pate MF. Thermal regulation pediatrics: principles and practice. 3rd ed. Philadelphia, USA: Lippincott-Williams and Wilkins 1999.

[26] Cabanac M. Temperature regulation. Annu Rev Physiol 1975; 37: 415-39. [http://dx.doi.org/10.1146/annurev.ph.37.030175.002215] [PMID: 123725]

[27] Covalesky ME, Russoniello CR, Malinowski K. Effects of show-jumping performance stress on plasma cortisol and lactate concentrations and heart rate and behaviour in horses. J Equine Vet Sci 1992; 12(4): 244-51. [http://dx.doi.org/10.1016/S0737-0806(06)81454-1]

[28] Visser EK, van Reenen CG, van der Werf JT, et al. Heart rate and heart rate variability during a novel object test and a handling test in young horses. Physiol Behav 2002; 76(2): 289-96. [http://dx.doi.org/10.1016/S0031-9384(02)00698-4] [PMID: 12044602]

[29] Stucke D, Große Ruse M, Lebelt D. Measuring heart rate variability in horses to investigate the autonomic nervous system activity - Pros and cons of different methods. Appl Anim Behav Sci 2015; 166: 1-10. [http://dx.doi.org/10.1016/j.applanim.2015.02.007]

[30] von Borell E, Langbein J, Després G, et al. Heart rate variability as a measure of autonomic regulation of cardiac activity for assessing stress and welfare in farm animals -- a review. Physiol Behav 2007; 92(3): 293-316. [http://dx.doi.org/10.1016/j.physbeh.2007.01.007] [PMID: 17320122]

[31] Peeters M, Sulon J, Beckers J-F, Ledoux D, Vandenheede M. Comparison between blood serum and salivary cortisol concentrations in horses using an adrenocorticotropic hormone challenge. Equine Vet J 2011; 43(4): 487-93. [http://dx.doi.org/10.1111/j.2042-3306.2010.00294.x] [PMID: 21496072] 
[32] Shanahan S. Trailer loading stress in horses: behavioral and physiological effects of nonaversive training (TTEAM). J Appl Anim Welf Sci 2003; 6(4): 263-74. [http://dx.doi.org/10.1207/s15327604jaws0604_1] [PMID: 14965781]

[33] Hart KA. The use of cortisol for the objective assessment of stress in animals: pros and cons. Vet J 2012; 192(2): 137-9. [http://dx.doi.org/10.1016/j.tvj1.2012.03.016] [PMID: 22534187]

[34] Federal Food Safety and Veterinary Office FSVO,Tierschutz-Kontrollhandbuch Pferde. 2012. Available at: http://www.blv.admin.ch/ themen/tierschutz/ 05466/05642/ index.html?lang=de [cited: 01 September 2012];

[35] Salimetrics Europe Ltd, Salivary Assay Kits - 1-3002 Cortisol. 2012. Available at: http://www.salimetrics.com/salivary-assay-kits [cited: 01 September 2012];

[36] R Core Team (R Foundation for Statistical Computing),R: A language and environment for statistical computing. 2012. Available at: http://www.r-project.org/ [cited: 01 September 2012];

[37] Pinheiro JC, Bates DM, S DebRoy, D Sarkar. nlme: linear and nonlinear mixed effects models. 2012. Available at: http://cran.r-project.org/web/packages/nlme/ [cited: 01 September 2012];

[38] Bates DM, Maechler M, Bolker B. lme4: linear mixed-effects models using S4 classes. 2012. Available at: http://cran.r-project.org/web/packages/lme4/index.html [cited: 01 September 2012];

[39] Burnham K, Anderson D. Model selection and multi-model inference. 2nd ed. New York, USA: Springer-Verlag 2002.

[40] Patt A, Gygax L, Wechsler B, Hillmann E, Palme R, Keil NM. The introduction of individual goats into small established groups has serious negative effects on the introduced goat but not on resident goats. Appl Anim Behav Sci 2012; 138(1-2): 47-59. [http://dx.doi.org/10.1016/j.applanim.2012.02.012]

[41] Krüger M. Die Temperaturwirkung von Farben in der bildenden Kunst eine Suche nach den Ursachen und der Funktionsweise des WarmKalt-Kontrastes. 1st ed. Osnabrück, Germany: Andere Verlag 2003.

[42] Hama H, Yogo M, Matsuyama Y. Effects of stroking horses on both humans' and horses' heart rate responses. Jpn Psychol Res 1996; 38(2): 66-73. [http://dx.doi.org/10.1111/j.1468-5884.1996.tb00009.x]

[43] Bridgeman DJ, Pretty GM, Tribe A. Heart rate synchronisation of dressage horse and rider during warm up period for a competition dressage test In: Proceedings Australian Equine Science Symposium. 2006; pp. 1-16.

[44] Chamove AS, Crawley-Hartrick OJ, Stafford KJ. Horse reactions to human attitudes and behaviour. Anthrozoos 2002; 15(4): 323-31. [http://dx.doi.org/10.2752/089279302786992423]

[45] Rietmann T, Stuart AE, Bernasconi P, Stauffacher M, Auer JA, Weishaupt MA. Assessment of mental stress in warmblood horses: heart rate variability in comparison to heart rate and selected behavioural parameters. Appl Anim Behav Sci 2004; 88(1-2): 121-36. [http://dx.doi.org/10.1016/j.applanim.2004.02.016]

[46] Fureix C, Pagès M, Bon R, Lassalle J-M, Kuntz P, Gonzalez G. A preliminary study of the effects of handling type on horses' emotional reactivity and the human-horse relationship. Behav Processes 2009; 82(2): 202-10. [http://dx.doi.org/10.1016/j.beproc.2009.06.012] [PMID: 19591910]

[47] McDonnell S. The equid ethogram: a practical field guide to horse behaviour. 1st ed. Lexington, USA: Eclipse Press 2003.

[48] Turner J, Perkins A, Kirkpatrick J. Elimination marking behaviour in feral horses. Can J Zool 1981; 59(8): 1561-6. [http://dx.doi.org/10.1139/z81-212]

[49] Loeffler K. Anatomie und Physiologie der Haustiere. 10th ed. Stuttgart, Germany: Verlag Eugen Ulmer 2002.

[50] Cross DT, Threlfall WR, Kline RC. Telemetric monitoring of body temperature in the horse mare. Theriogenology 1991; 36(5): 855-61. [http://dx.doi.org/10.1016/0093-691X(91)90351-D] [PMID: 16727054]

[51] Green A, Gates R, Lawrence L. Measurement of horse core body temperature. J Therm Biol 2005; 30(5): $370-7$. [http://dx.doi.org/10.1016/j.jtherbio.2005.03.003]

[52] Piccione G, Giannetto C, Marafioti S, et al. Daily rhythms of rectal temperature and total locomotor activity in trained and untrained horses. J Vet Behav Clin Appl Res 2011; 6(2): 115-20. [http://dx.doi.org/10.1016/j.jveb.2010.11.003]

[53] Wolff A, Hausberger M, Le Scolan N. Experimental tests to assess emotionality in horses. Behav Processes 1997; 40(3): $209-21$. [http://dx.doi.org/10.1016/S0376-6357(97)00784-5] [PMID: 24895882]

[54] Glatthaar A. Ethogram of the horse. Berlin, Germany: Weißensee Verlag 2009.

[55] Dietz O, Huskamp B. Handbuch pferdepraxis. 2nd ed. Stuttgart, Germany: Enke Verlag 1999.

[56] Minero M, Zucca D, Canali E. A note on reaction to novel stimulus and restraint by therapeutic riding horses. Appl Anim Behav Sci 2006; 97(2-4): 335-42. [http://dx.doi.org/10.1016/j.applanim.2005.07.004]

[57] Voss B, Mohr E, Krzywanek H. Effects of aqua-treadmill exercise on selected blood parameters and on heart-rate variability of horses. J Vet Med A Physiol Pathol Clin Med 2002; 49(3): 137-43. 
[http://dx.doi.org/10.1046/j.1439-0442.2002.00420.x] [PMID: 12019954]

[58] Schmidt A, Biau S, Möstl E, et al. Changes in cortisol release and heart rate variability in sport horses during long-distance road transport. Domest Anim Endocrinol 2010; 38(3): 179-89.

[http://dx.doi.org/10.1016/j.domaniend.2009.10.002] [PMID: 19962266]

[59] Lebelt D, Schönreiter S, Zanella AJ. Salivary cortisol in stallions: the relationship with plasma levels, daytime profile and changes in response to semen collection. Pferdeheilkunde 1996; 12(4): 411-4.

[60] Schmidt A, Möstl E, Wehnert C, Aurich J, Müller J, Aurich C. Cortisol release and heart rate variability in horses during road transport. Horm Behav 2010; 57(2): 209-15.

[http://dx.doi.org/10.1016/j.yhbeh.2009.11.003] [PMID: 19944105]

[61] Aurich J, Wulf M, Ille N, et al. Effects of season, age, sex, and housing on salivary cortisol concentrations in horses. Domest Anim Endocrinol 2015; 52: 11-6. [http://dx.doi.org/10.1016/j.domaniend.2015.01.003] [PMID: 25700267]

[62] Murphy BA, Martin AM, Elliott JA. Light: dark, circadian, and ultradian regulation of motor activity and skeletal muscle gene expression in the horse. J Equine Vet Sci 2009; 29(5): 313-5. [http://dx.doi.org/10.1016/j.jevs.2009.04.020]

(C) Burla et al.; Licensee Bentham Open.

This is an open access article licensed under the terms of the Creative Commons Attribution-Non-Commercial 4.0 International Public License (CC BY-NC 4.0) (https://creativecommons.org/licenses/by-nc/4.0/legalcode), which permits unrestricted, non-commercial use, distribution and reproduction in any medium, provided the work is properly cited. 